\title{
Insect evolution toward aquatic habitats; reassessment of antennal sensilla in the water bug families Ochteridae, Gelastocoridae and Aphelocheiridae (Hemiptera: Heteroptera: Nepomorpha)
}

\author{
Agnieszka Nowińska \\ University of Silesia in Katowice, Faculty of Natural Science, Institute of Biology, \\ Biotechnology and Environmental Protection, 40-007 Katowice, Bankowa 9, Poland \\ agnieszka.nowinska@us.edu.pl \\ Jolanta Brożek \\ University of Silesia in Katowice, Faculty of Natural Science, Institute of Biology, \\ Biotechnology and Environmental Protection, 40-007 Katowice, Bankowa 9, Poland
}

\begin{abstract}
The first comparative morphology study on antennal sensilla of Ochteridae, Gelastocoridae and Aphelocheiridae, carried out with the use of a scanning electron microscope, is provided. Our research hypothesis was: the antennal sensilla of the studied families reflect their different adaptations for use in aquatic habitats, while maintaining a common set of sensilla similar to other water bugs (Nepomorpha). Therefore, the number and placement of antennal sensilla of several species in the mentioned families were studied using scanning electron microscopy. Nine main types of mechano- chemo- and thermohygroreceptive sensilla were confirmed on their surface, including sensilla trichodea, chaetica, club-like, campaniformia, basiconica, coeloconica, plate-like, ampullacea and sensilla placodea multilobated. While seven of these were already documented in other species, two of them (sensilla plate-like and placodea multilobated) were yet to be documented on the antennae of Nepomorpha. All families display differences in the shape and length of antennae as well as among sensilla types. These findings support our hypothesis regarding differences in sensillar structures among families adapted differently to suitable niches. Differences between these families and previously studied nepomorphan taxa (Nepoidea) were also documented. However, the general set of sensilla observed on the antennae of the studied species is very similar to the one documented in Nepoidea. Therefore, we confirmed our assumptions regarding similarities in antennal sensilla between the studied families and other nepomorphan insects.
\end{abstract}




\section{Keywords}

antennal sensilla - morphology - nepomorpha - Ochteridae - Gelastocoridae - Aphelocheiridae

\section{Introduction}

Members of the true water bugs, or Nepomorpha have long attracted the attention of researchers due to the possession of diverse body structures and lifestyles. These nepomorphan insects, being predaceous (except most corixids, that may also be scavengers or consume algae), are one of the most specialized groups among heteropterans. The Nepomorpha are recognized as a group of secondarily aquatic bugs among the suborder of Heteroptera (Popov, 1971). Most remaining taxa in this infraorder are terrestrial, except the Gerromorpha, or semi-aquatic bugs (Polhemus et al., 1995; Schuh \& Slater, 1995).

The water bugs currently classified as the Nepomorpha, include about 2000 species worldwide (Polhemus et al., 1995), with 13 families recognized in this infraorder (Nieser, 2002). By contrast, 11 families were distinguished by Chen et al.(2005) and were grouped differently in seven superfamilies (Hebsgaard et al., 2004; Brożek, 2014; Ye et al., 2020).

Evolutionary transitions of insects from terrestrial to aquatic habitats provide important insights into how their organismal traits have responded to major adaptive shifts (Crespo, 2011). Opportunities for documentation such inferences are limited, because many secondarily aquatic insect taxa are still lacking detailed morphological data.

The beginning of diversification of the whole nepomorphan group is estimated to have occurred in the late Permian (about 263 Ma) (Ye et al., 2020). It is certain, on the basis of fossils, that they existed during the midTriassic and are a divergence from the terrestrial group (Grimaldi \& Engel, 2005). Important examples of Nepomorpha are represented by some family groups: Ochteridae, Gelastocoridae, which are terrestrial/hydrophiine bugs, which comprise water margin inhabitants (China, 1955; Popov, 1971; Schuh \& Slater, 1995; Papáček, 2001; Kment \& Jindra, 2008), as well as Aphelocheiridae and the other remaining families (Nepidae, Belostomatiade, Corixiidae, Naucoridae, Notomectidae, Pleidae and Helotrephidae) which live submerged in water (Polhemus \& Polhemus, 1988).

Popov (1971) hypothesized that a protoheteropteran terrestrial lineage gave rise, among others, to protoochterids that resulted in three main branches of aquatic bugs in the mid-Triassic period: The first branch was Nepoidea (Nepidae and Belostomatidae), the second was Corixoidea (Corixidae) and the third branch at first led to Ochteroidea and next to Naucoroidea, Notonectoidae and Pleoidea. The present study focuses on the sensillar system of the antennae in three particular families (Ochteridae, Gelastocoridae and Aphelocheiridae) which are considered suitable targets for studying the evolution of organismal traits resulting from multiple transitions between land and water.

The family Ochteridae consists of 80 species, and displays its highest diversity in tropical regions. The four-segmented antennae are easily visible because they extend over the head (Chen et al., 2005). In contrast with nepomorphan groups which are fully aquatic, Ochteridae are considered to be semi-aquatic (hydrophiine), or even riparian (Chen et al., 2005). They inhabit mossy rocks along streams, walls of waterfalls, sand banks and other edges of water reservoirs (Zettel \& Lane, 2010). They are zoophagous and are believed to prey on small invertebrates such as dipteran larvae (Chen et al., 2005). Many members 
of the Ochteridae are terrestrial and are often found at long distances from aquatic habitats (Ye et al., 2020).

Gelastocoridae consists of two subfamilies, Gelastocorinae and Nerthrinae (Todd, 1955). They all have four-segmented antennae concealed in groves beneath the eyes (Todd, 1955; Chen et al., 2005), not visible from the dorsal perspective. The Gelastocoridae are considered riparian or even terrestrial bugs (similar to Ochteridae), which distinguishes them from most Nepomorphan families in terms of habitat. Several species of Nerthra have even been collected far from water. At least three species have been found under water (La Rivers, 1953). However given the gelastocorids' habitat, this particularity is rather the exception. There is no documentation regarding their ability to fly. Some species even have fused hemelytra which makes them unable to fly (Chen et al., 2005). They are predatory bugs (Schuh \& Slater, 1995) and have the ability to jump while hunting prey.

Aphelocheiridae, similar to the other taxa previously discussed, have four-segmented antennae. In contrast to Gelastocoridae, the antennae in Aphelocheiridae are easily visible, since they are not concealed. Species of Aphelocheirus are known for their ability to stay submerged underwater (Andersen \& Weir, 2004), which is possible due to their plastron respiration system that also allows them to complete their entire life cycle underwater (Polhemus \& Polhemus, 1988). They feed on immature forms of various aquatic insects such as Ephemeroptera and Trichoptera.

While there are no doubts about the classification of Gelastocoridae and Ochteridae they both belong to the superfamily Ochteroidea (Štys \& Jansson, 1988; Hebsgaard, 2004; Brożek, 2014; Ye et al., 2020) the systematic position of Aphelocheiridae in Nepomorpha isunclear. In previous classifications the taxon was a subfamily of Aphelocheirinae (Polhemus \& Polhemus, 1988) within the
Naucoridae, but later was elevated to family position (Štys \& Jansson, 1988). Aphelocheiroidea, a new superfamily, was formed afterwards, consisting of two families, Aphelocheiridae and Potamocoridae (Hebsgaard, 2004), after which they were collapsed into a single family in the aforementioned superfamily (Brożek, 2014). A recent study gave conflicting results and Aphelocheiridae returned to Naucoroidea (Ye et al., 2020). Therefore, in this study we consider the morphology of sensilla on the family level and do not exclude Aphelocheiridae from belonging to any superfamily (Aphelocheiroidea or Naucoroidea).

Among sensory organs, the antennae usually have the highest concentration and diversity. External sensilla possess an external cuticular shaft of various sizes and shapes, and a socket or joint that anchors the process in the surrounding epidermis, so they present many different morphologies adapted to their modality. They play a mechanical, chemosensory and thermo-hygroreceptive function (Slifer, 1970; Altner \& Prillinger, 1980; Hallberg \& Hansson, 1999; Zacharuk, 1980; Shields, 2010).

Sensillar systems are especially important for aquatic insects which live in dense, dark, highly complex habitat conditions or species with poor vision capabilities (Brönmark \& Hanssons, 2000; Wisenden, 2000). Moreover, in aquatic insects, the distinction between taste and olfaction is vague, but is still used based on the structure and particular location of the sensilla, or behavioral response (Zacharuk, 1980; Crespo, 2011).

Until now, several types of labial sensilla (sensilla trichodea, chaetica, squamiformia, basiconica, club-like, paddle-like, cupolashaped, and peg sensilla) have been described in numerous species of Nepomorpha (Brożek, 2013, 2014). More general research has also been done on the basal shapes of the antennae and distributions of some sensilla in representatives of nepomorphan families (Popov, 1971; Schuh \& Slater, 1995; Chen et al., 2005). 
Moreover, a small amount of data about the morphology and distribution of more visible sensilla (trichodea or basiconica) on the surface of antennae of Notonecta glauca, Plea leachi, Nepa cinerea, Ranatra linearis and Sigara striata has been presented by Chaika \& Sinitsina (1999), although the possible functions of the sensilla have not been indicated. However, newer morphological studies of antennal sensilla from species of Nepoidea, performed by Nowińska \& Brożek (2019), have shown some inconsistencies in comparison to data from Chaika \& Sinitsina (1999).

Although some papers (mentioned above) have shed light on the antennal structures and reception of environmental stimuli in some nepomorphan species, the understanding of the olfactory system in water bugs is still poor. Limited information on morphology and physiology is available, for a small number of species. The identification and description of antennal sensilla, through the use of scanning electron microscopy (SEM), for a comprehensive understanding of the sensory systems of the antennae, was performed only for a few Nepoidea species (Nowińska \& Brożek, 2019).

We expect that the antennal sensilla of studied species from these families differ, because of their various adaptations to the water habitat. No studies of fine morphology and ultrastructure have been performed so far on these representatives of the families.

The research hypothesis is: the antennal sensilla of the studied families reflect their different adaptations for use in aquatic habitats, while maintaining a common set of sensilla similar to other water bugs (Nepomorpha).

Therefore, the aim of this study is to examine the morphological diversity and distribution of sensilla on the antennae, assign probable functions and compare them with homologous structures observed in other nepomorphan groups, as well as other terrestrial and semi-aquatic heteropteran groups.

\section{Materials and methods}

The material was obtained from the collections of the Natural History Museum in Vienna, Zoological Museum of the State Moscow University and Hungarian Natural History Museum in Budapest. Additional species of Nerthra and Gelastocoris have been donated by Ping-ping Chen. All specimens have been cleaned in an ultrasound cleaner, the antennae have been dissected, dried in ethanol, mounted, sputtered with gold or chromium and observed with the use of the scanning electron microscopes Phenom XL and Hitachi UHR FE-SEM SU 8010 in the scanning microscopy laboratory of the Faculty of Natural Science, Institute of Biology, Biotechnology and Environmental Protection of Silesian University in Katowice. We follow the terminology and classification reported in other papers on antennal sensilla of insects (Altner \& Prillinger, 1980; Nowińska \& Brożek, 2019).

The antennae of eight species from three families have been studied:

Aphelocheiridae: Aphelocheirus aestivalis (Fabricius, 1803)

Obtained from Hungarian Natural History Museum

Label data: Seine bei Rouen, Gallia, coll. Horvath

Ochteridae: Ochterus marginatus (Latreille, 1804)

Obtained from Hungarian

Natural History Museum

Label data: Japan, Okayama

H. Sauter, det. P. Chen

Gelastocoridae: Gelastocorinae:

Gelastocoris sp.

Obtained from Zoological

Museum of the State

Moscow University

Species identified in the

Museum, the place of

collection cannot be

confirmed

Downloaded from Brill com04/26/2023 09:29:35AM 
Gelastocoris flavus flavus

(Guérin-Méneville,1835)

Obtained thanks to donation from Dr Ping-ping Chen

Label data: Bronopondo, road to Brownsweg, ponds, leg. N. NieserSN229/30, det. P. Chen

Nerthrinae:

Nerthra femoralis

(Montandon,1899)

Obtained from Natural

History Museum in Vienna

Species identified in the

Museum, the place of

collection cannot be

confirmed

Nerthra fuscipes

(Guérin-Méneville,1843)

Obtained from Hungarian

Natural History Museum

Label data: Mexico, Procopp

Nerthra ampliata

(Montandon,1899)

Obtained from Hungarian

Natural History Museum

Label data: N. Guinea, Biro

1900, Stephansort, Astro-

labe Bay

Nerthra ranina

(Herrich-Schäffer,1853)

Obtained thanks to dona-

tion from Dr Ping-ping Chen

Label data: Argentina, det.

Nieser \& Chen

\section{Results}

\section{Gross morphology of the antennae}

Differences in the shapes of the species' antennae have been observed. The length of the thin antennae of Ochterus is approximately $75^{\circ} \mu \mathrm{m}$. The first two antennomeres are shorter (130 and $120 \mu \mathrm{m})$ and wider than the other two (230 and $270 \mu \mathrm{m})$. Whole antennae are visibly covered with hair-like sensilla (fig. 1a). The antennae of Gelastocoris and Nerthra are visibly thicker. In both, the last antennomer remains the longest (around $300 \mu \mathrm{m}$ in Gelastocoris and around 400/500 $\mu \mathrm{m}$ in Nerthra) but there is a difference in the length of the third antennomer. In Gelastocoris it is much shorter $(170 \mu \mathrm{m})$ than in Nerthra (around 200-300 $\mu \mathrm{m}$ ), but in both cases the third antennomer is the shortest (figs 2a, 4b). In Aphelocheirus we observe around $1 \mathrm{~mm}$ long and thin four-segmented antennae. The first two antennomers (scapus and pedicel) are shorter (around 150 and $170 \mu \mathrm{m}$ ), while the other two (antennomers of flagellum) are visibly longer (300 and $490 \mu \mathrm{m})$. The antennae are rather smooth, with only some groups of thick sensilla visible on the surface (fig. $5 \mathrm{a}$ ).

\section{Antennal sensilla}

In this study, based on morphological characteristics, nine main types of sensilla have been found (sensilla trichodea, chaetica, club-like, campaniformia, basiconica, coeloconica, ampullacea, plate-like and multilobated) (fig. 6). Some of these types have been described in other insects (McIver, 1975; Zacharuk, 1980), as well as in some heteropteran insects (Brożek, 2013, 2014; Nowińska \& Brożek, 2019). Sensilla trichodea, club-like, campaniformia and basiconica (subtype 1), because of their flexible sockets, are believed to play a mechanoreceptive function. Sensilla basiconica (subtype 2, 3 and 4) function as chemoreceptive sensilla given their porous surface and inflexible socket. Pores on the surface of these sensilla indicate an olfactory function. Another function is thermo-hygroreception and it is performed by sensilla ampullacea and sensilla coeloconica. Taking into account the external morphological features (shape and build) of sensilla platelike and multilobated, we assume that they 

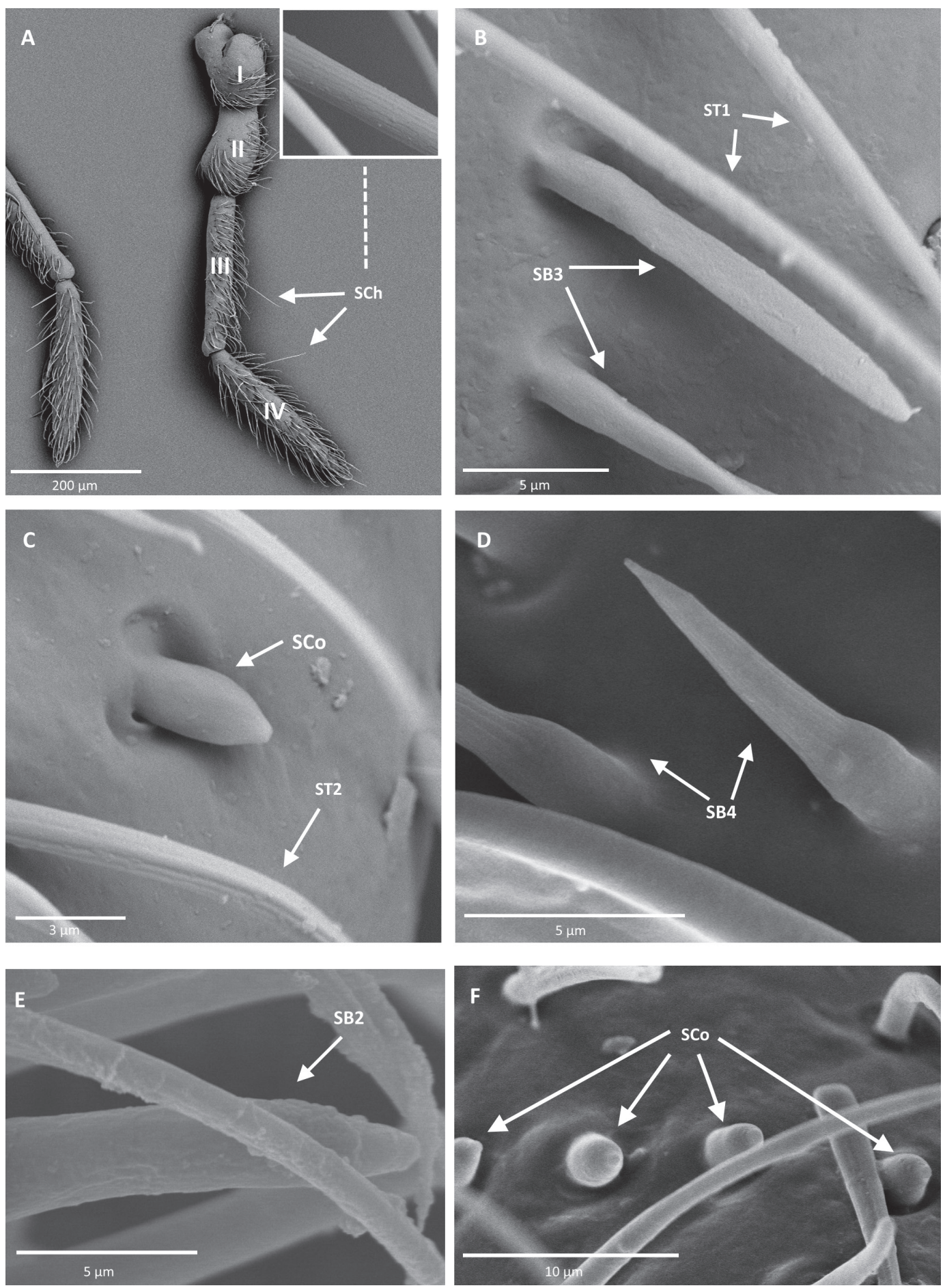

FIGURE 1 Ochterus marginatus; SCh, sensilla chaetica; SB, sensilla basiconica; ST, sensilla trichodea; SCo, sensilla coeloconica. 

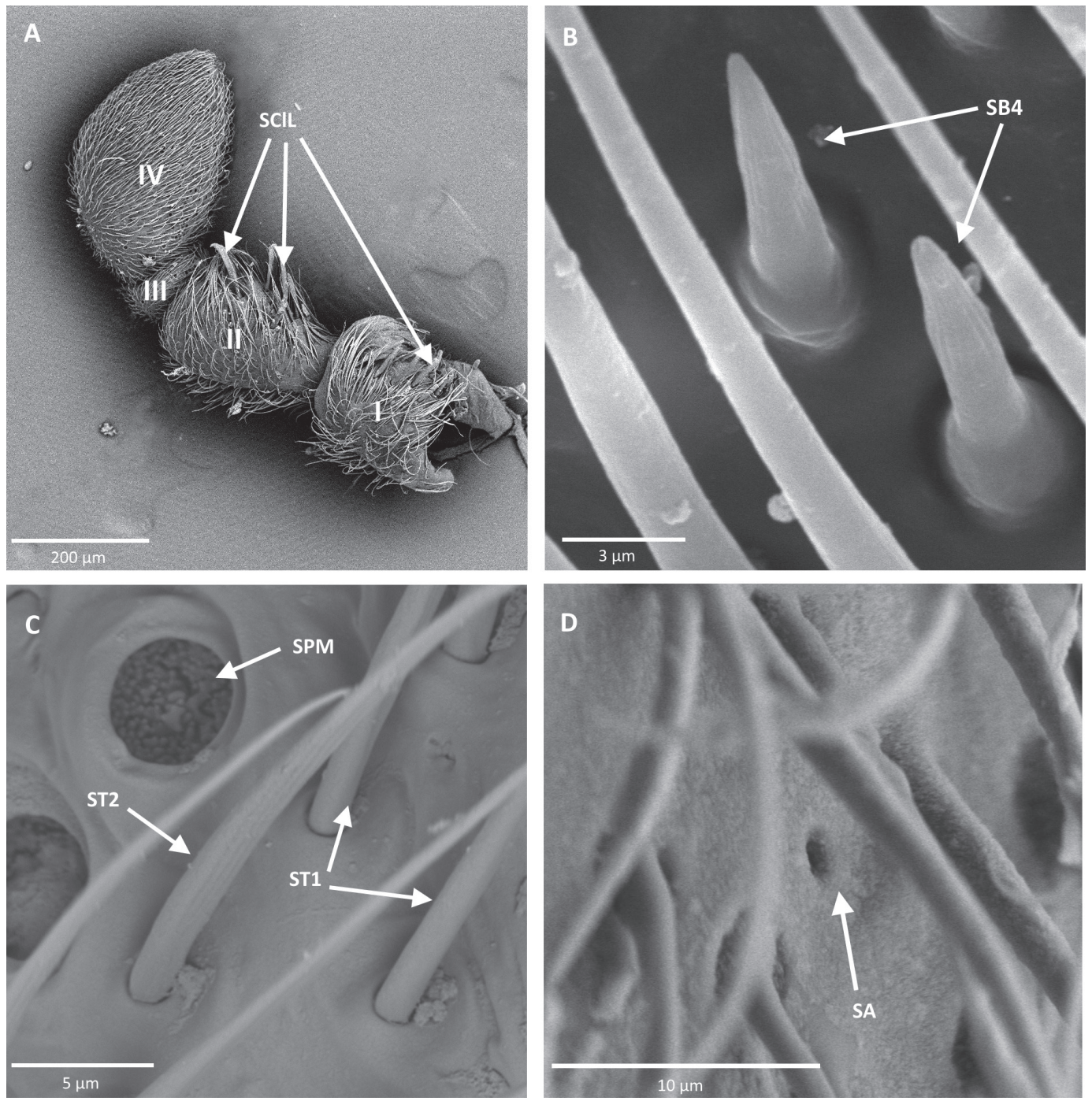

FIGURE 2 A, B, Gelastocoris flavus flavus; C, D, Gelastocoris sp.; SClL, sensilla club-like; SA, sensilla ampullacea; ST, sensilla trichodea; SPM, sensilla placodea multilobated; SB, sensilla basiconica.

perform a chemoreceptive function. Morphological features and distribution of antennal sensilla are summarized in table 1 and the distribution of sensilla on the antennae is reported in specific figures (figs 1a, 2a, 4b, 5a).

Sensilla trichodea - these are usually long sensilla resembling hair, tapered from the base to the tip and curved towards the antennal shaft or they are nearly straight hairs. Frequently, they occur in large numbers, less often as a single hair. They are embedded into flexible sockets. According to the surface shape and length, two subtypes have been distinguished:

1. Sensilla trichodea $\left(\mathrm{ST}_{1}\right)$ - these are long sensilla trichodea, blunt-tipped straight hairs with a smooth surface. They are usually numerous on the surface of the antennae and have been found in all of the studied species (figs $1 b, 2 c, 4 f$ ).

2. Sensilla trichodea $\left(\mathrm{ST}_{2}\right)$ - these are long sensilla trichodea, blunt-tipped and 

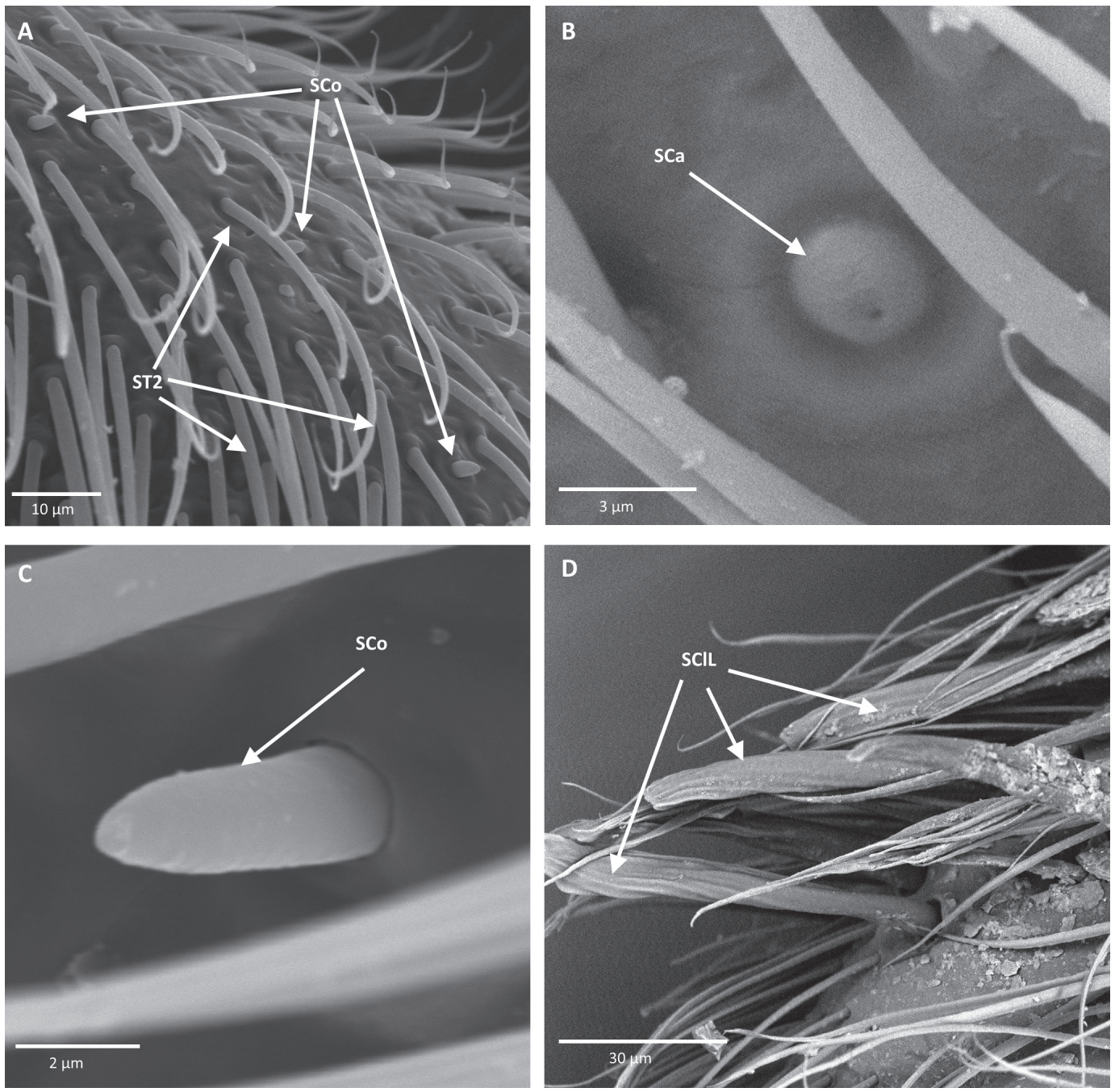

FIGURE 3 Gelastocoris flavus flavus; ST, sensilla trichodea; SCo, sensilla coeloconica; SCa, sensilla campaniformia; SClL, sensilla club-like.

curved towards the antennal shaft, with a ribbed surface. They are slightly wider than ST1. They have been found in Ochterus, Gelastocoris and Nerthra on all of the antennomeres (figs 1c, 2c, 3a).

Sensilla chaetica (SCh) - these sensilla are more pronounced than sensilla trichodea, mainly in length and width. They are ribbed and inserted in flexible sockets, rising much higher than sensilla trichodea, which makes them well visible. They have been found in
Ochterus on all antennomeres, where they occur singularly and in Nerthra ampliata as a single sensillum on the first antennomere (figs 1a, 4d).

Sensilla club-like (SCIL) - these sensilla are more pronounced and thicker than sensilla trichodea. They are ribbed, flattened and rise from flexible sockets. They occurred in Ochteridae. In G. flavus and Gelastocoris sp. on the $1^{\text {st }}$ and $2^{\text {nd }}$ antennomeres, these sensilla occur in groups and in Nerthra femoralis on 

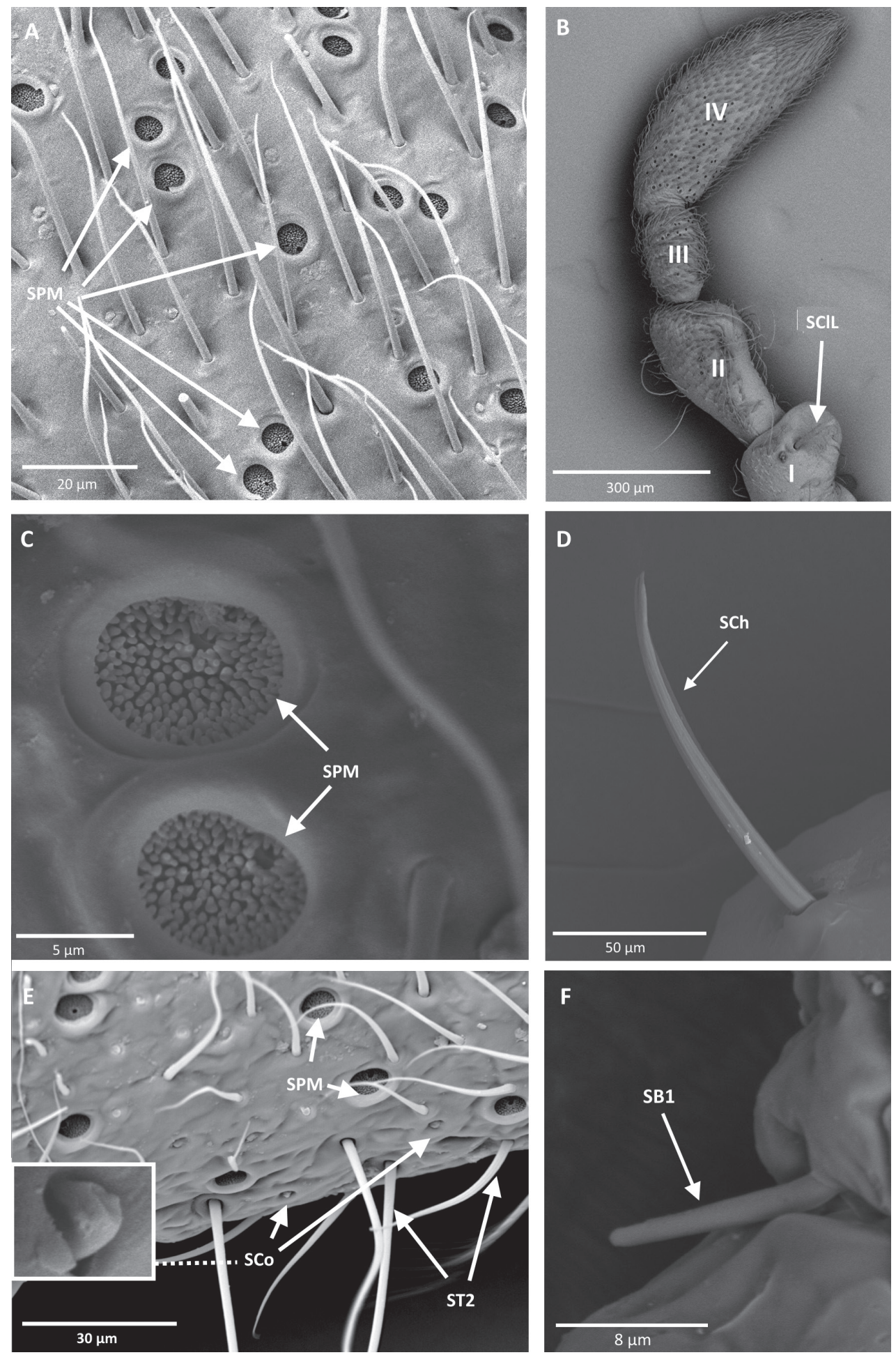

FIgURE 4 A, B, C, E, Nerthra femoralis; D, Nerthra ampliata; F, Nerthra fuscipes; SPM, sensilla placodea multilobated; SCIL, sensilla club-like; SCh, sensilla chaetica; SCo, sensilla coeloconica; ST, sensilla trichodea; $\mathrm{SB}$, sensilla basiconica. 

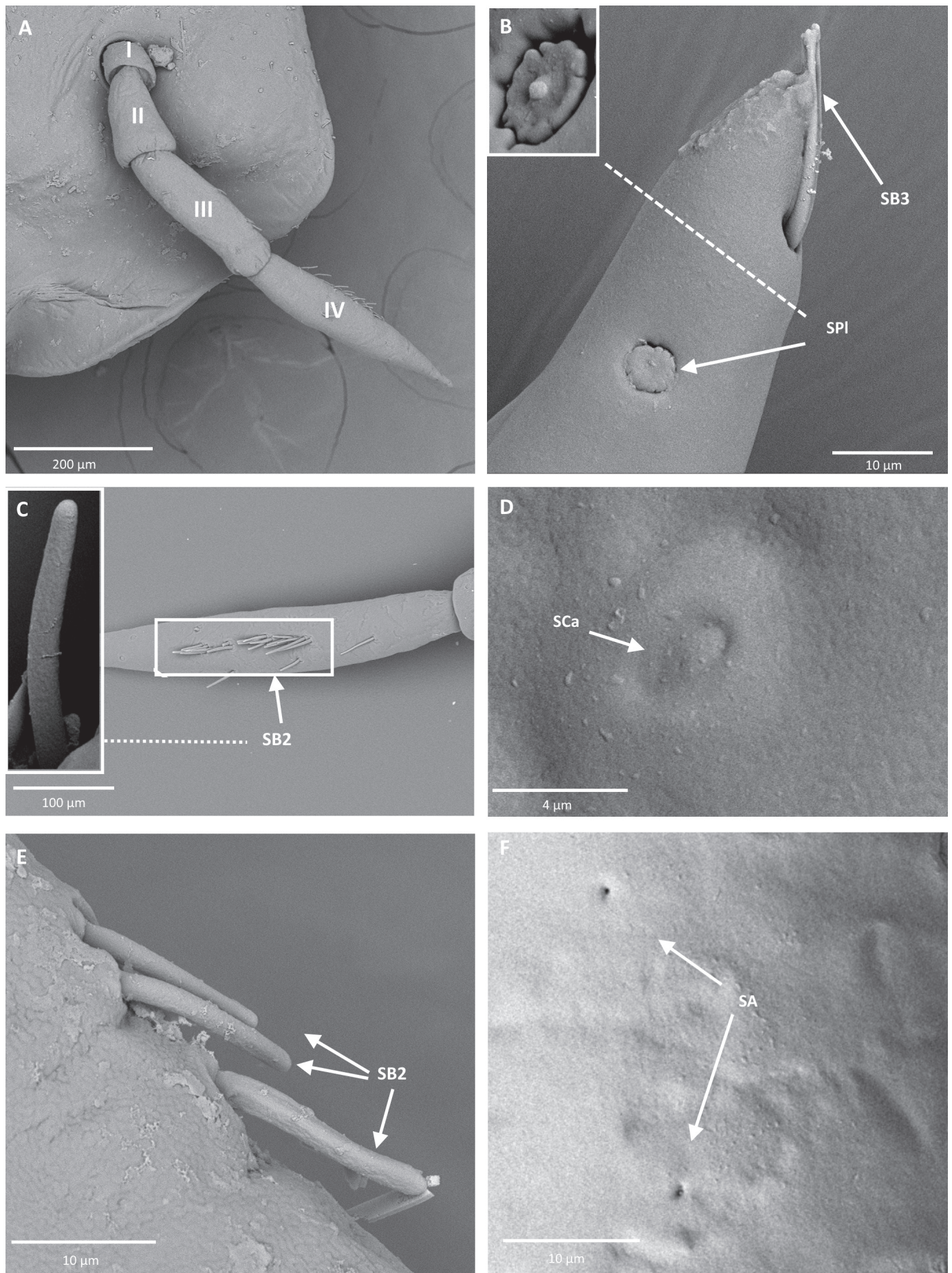

FIGURE 5 Aphelocheirus aestivalis; SPl, sensilla plate-like; SB, sensilla basiconica; SCa, sensilla campaniformia; SA, sensilla ampullacea. 

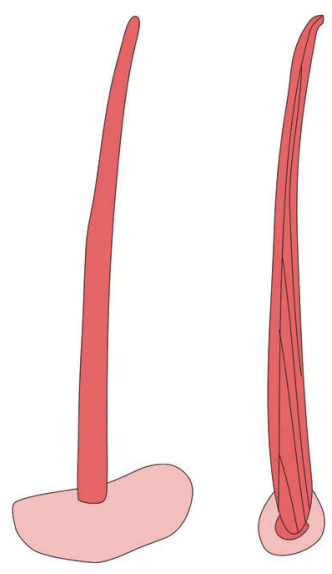

ST1

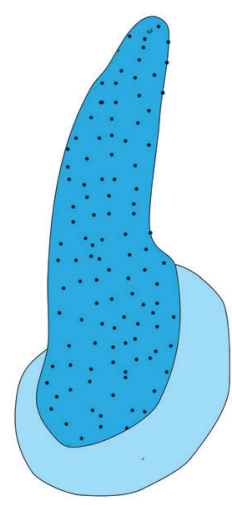

SB2

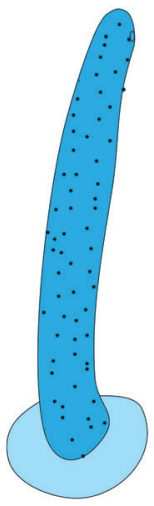

SB3

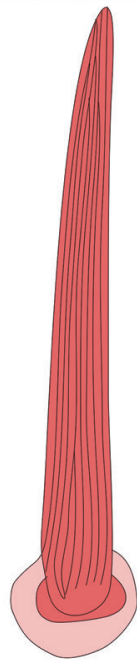

$\mathrm{SCh}$

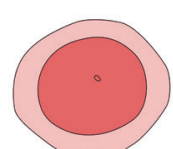

$\mathrm{SCa}$

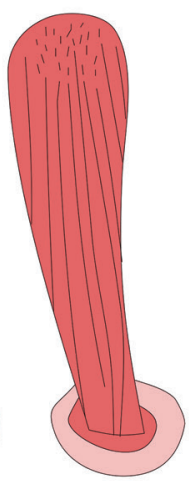

SCIL

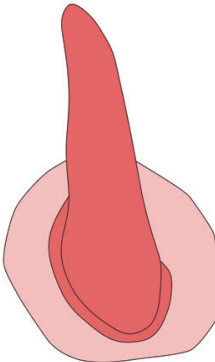

SB1

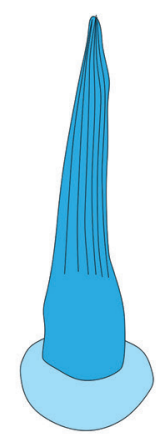

SB4

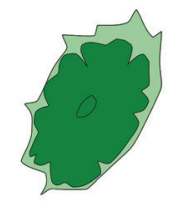

SPI

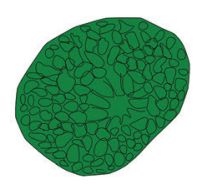

SPM

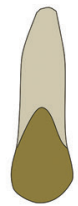

SA

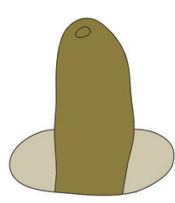

SCo

FIGURE 6 Shapes of sensilla; ST, sensilla trichodea; SCh, sensilla chaetica; SCa, sensilla campaniformia; SClL, sensilla club-like; SB, sensilla basiconia; SPl, sensilla plate-like; SPM, sensilla placodea multilobated; SA, sensilla ampullacea; SCo, sensilla coeloconica. 
TABLE 1 The presence of sensilla types on the antennae, according to their function and their arrangement

\begin{tabular}{|c|c|c|c|c|c|c|}
\hline Species & MS & CHS & THS & $\begin{array}{l}\text { UNF } \\
\text { (olfactory?) }\end{array}$ & $\begin{array}{l}\text { sensilla on } \\
\text { antennomeres (anm) }\end{array}$ & Sensilla quantity \\
\hline Ochterus & $\mathrm{ST}_{1}$ & $\mathrm{SB}_{2}$ & SA & & ST all anm & ST numerous \\
\hline \multirow[t]{5}{*}{ marginatus } & $\mathrm{ST} 2$ & $\mathrm{SB}_{3}$ & SCo & & SCh all anm & SCh singularily \\
\hline & $\mathrm{SCh}$ & $\mathrm{SB}_{4}$ & & & $\mathrm{SB} 24^{\text {th }}$ anm & $\mathrm{SB} 2$ few \\
\hline & $\mathrm{SB}_{1}$ & & & & $\mathrm{SB}_{3}$ the $3^{\text {rd }}$ and $4^{\text {th }}$ anm & $\mathrm{SB}_{3}$ numerous \\
\hline & & & & & $\mathrm{SB} 42^{\text {nd }}$ and $4^{\text {th }}$ anm & SB4 singularily or few \\
\hline & & & & & $\mathrm{SCo} 3^{\text {rd }}$ and $4^{\text {th }}$ anm & SCo singularily or few \\
\hline Gelastocoris & $\mathrm{ST}_{1}$ & $\mathrm{SB} 2$ & SA & SPM & ST all anm & ST numerous \\
\hline \multirow[t]{5}{*}{$s p$} & $\mathrm{ST} 2$ & $\mathrm{SB}_{3}$ & & & $\operatorname{SClL} 1^{\text {st }}$ and $2^{\text {nd }}$ & SCIL occur in groups \\
\hline & SClL & $\mathrm{SB}_{4}$ & & & anm SB2 $2^{\text {nd }}-4^{\text {th }}$ anm & $\mathrm{SB} 2$ singularily \\
\hline & $\mathrm{SB}_{1}$ & & & & $\mathrm{SB}_{3}$ last anm & $\mathrm{SB}_{3}$ numerous \\
\hline & & & & & $\mathrm{SB}_{4} 2^{\text {nd }}-4^{\text {th }}$ anm & $\mathrm{SB} 4$ singularily \\
\hline & & & & & $\mathrm{SPM} 3^{\text {rd }}$ and $4^{\text {th }}$ anm & SPM numerous \\
\hline Gelastocoris & ST1 & $\mathrm{SB}_{2}$ & SA & SPM & ST all anm & ST numerous \\
\hline \multirow[t]{5}{*}{ flavus flavus } & ST2 & $\mathrm{SB}_{4}$ & SCo & & $\operatorname{SClL} 1^{\text {st }}$ and $2^{\text {nd }}$ anm & SClL occur in groups \\
\hline & SCa & & & & $\mathrm{SB} 22^{\text {nd }}-4^{\text {th }}$ anm & $\mathrm{SB} 2$ singularily \\
\hline & SClL & & & & $\mathrm{SB}_{4} 2^{\text {nd }}-4^{\text {th }}$ anm & $\mathrm{SB}_{4}$ occur in groups / line \\
\hline & $\mathrm{SB} 1$ & & & & SCo $2^{\text {nd }}$ anm & SCo few \\
\hline & & & & & $\mathrm{SPM} 3^{\text {rd }}$ and $4^{\text {th }}$ anm & SPM numerous \\
\hline Nerthra & ST1 & $\mathrm{SB}_{2}$ & SA & SPM & ST all anm & ST numerous \\
\hline \multirow[t]{4}{*}{ femoralis } & ST2 & & SCo & & SClL $1^{\text {st }}$ anm & SClL single \\
\hline & $\mathrm{SCa}$ & & & & $\mathrm{SB} 22^{\text {nd }}-4^{\text {th }}$ anm & $\mathrm{SB} 2$ singularily \\
\hline & SClL & & & & $\mathrm{SCo} 4^{\text {th }}$ anm & SCo in groups / singularily \\
\hline & $\mathrm{SB}_{1}$ & & & & $\mathrm{SPM} 3^{\text {rd }}$ and $4^{\text {th }}$ anm & SPM numerous \\
\hline \multirow{3}{*}{$\begin{array}{l}\text { Nerthra } \\
\text { fuscipes }\end{array}$} & ST1 & $\mathrm{SB}_{2}$ & SA & SPM & ST all anm & ST numerous \\
\hline & $\mathrm{ST} 2$ & & & & $\mathrm{SB} 22^{\text {nd }}-4^{\text {th }}$ anm & SB2 singularily \\
\hline & $\mathrm{SB}_{1}$ & & & & $\mathrm{SPM} 3^{\text {rd }}$ and $4^{\text {th }}$ anm & SPM numerous \\
\hline \multirow{4}{*}{$\begin{array}{l}\text { Nerthra } \\
\text { ampliata }\end{array}$} & ST1 & $\mathrm{SB} 2$ & SA & SPM & ST all anm & ST numerous \\
\hline & $\mathrm{ST} 2$ & & & & SCh $1^{\text {st }}$ anm & SCh single \\
\hline & $\mathrm{SCh}$ & & & & $\mathrm{SB} 22^{\text {nd }}-4^{\text {th }}$ anm & SB2 singularily \\
\hline & SB1 & & & & $\mathrm{SPM} 3^{\text {rd }}$ and $4^{\text {th }}$ anm & SPM numerous \\
\hline \multirow{5}{*}{$\begin{array}{l}\text { Nerthra } \\
\text { ranina }\end{array}$} & $\mathrm{ST}_{1}$ & $\mathrm{SB} 2$ & SA & SPM & ST all anm & ST numerous \\
\hline & $\mathrm{ST} 2$ & $\mathrm{SB}_{4}$ & SCo & & $\mathrm{SB} 22^{\text {nd }}-4^{\text {th }}$ anm & $\mathrm{SB} 2$ singularily \\
\hline & SB1 & & & & $\mathrm{SB} 42^{\text {nd }}$ and $4^{\text {th }}$ anm & $\mathrm{SB} 4$ singularily \\
\hline & & & & & $\mathrm{SCo} 4^{\text {th }}$ anm & SCo few \\
\hline & & & & & $\mathrm{SPM} 3^{\text {rd } \text { and } 4^{\text {th }} \text { anm }}$ & SPM numerous \\
\hline \multirow{4}{*}{$\begin{array}{l}\text { Aphelocheirus } \\
\text { aestivalis }\end{array}$} & $\mathrm{ST} 2$ & $\mathrm{SB} 2$ & SA & SPl & $\mathrm{ST} 3^{\text {rd anm }}$ & ST singularily \\
\hline & SCa & $\mathrm{SB}_{3}$ & & & $\mathrm{SB}_{2} 3^{\text {rd }}$ and $4^{\text {th }}$ anm & $\mathrm{SB} 2$ in groups \\
\hline & & & & & $\mathrm{SB}_{3}$ tip of the $4^{\text {th }}$ anm & $\mathrm{SB}_{3}$ single \\
\hline & & & & & $\mathrm{SPl} 4^{\text {th }}$ anm & SPl numerous \\
\hline
\end{tabular}


the $1^{\text {st }}$ antennomere, single sensillum clublike have been found figs. $2 a, 3 d, 4 b)$.

Sensilla campaniformia (SCa) - these are round plates with a single pore, embedded in flexible sockets. They have been documented only in a few species. However, this type is common for all insects so we believe it is also present in other species studied (figs $3 \mathrm{~b}, 5 \mathrm{~d}$ ).

Sensilla basiconica - these are long structures, thick and curved or tapered at the tip. They are inserted in inflexible sockets. We have distinguished four subtypes of these sensilla:

1. Sensilla basiconica (SB1) - this kind of sensilla is responsible for mechanoreception. It is present between the antennomeres and is being stimulated by the movement of each antennomere. It is a common type of sensilla on insects' antennae (fig. 4f).

2. Sensilla basiconica $\left(\mathrm{SB}_{2}\right)$ - these are sensilla basiconica with the same width along the whole surface and slightly rounded tip. They bear pores along the whole surface. $\mathrm{SB} 2$ have been found in all of the studied species. In Aphelocheirus on the $3^{\text {rd }}$ and $4^{\text {th }}$ antennomere, sensilla occur in groups. In Gelastocoris and Nerthra on the $2^{\text {nd }}-4^{\text {th }}$ antennomere, sensilla occur singularly. In Ochterus the most visible and significant are sensilla at the tip of the $4^{\text {th }}$ antennomere - one sensillum at the tip is surrounded by a few other SB2 (figs 1e, 5c, e).

3. Sensilla basiconica $\left(\mathrm{SB}_{3}\right)$ - these are porous sensilla basiconica, long and flattened along the whole length. They have been found in Ochterus on the third and fourth antennomere, in Gelastocoris on the last antennomere and in Aphelocheirus as a single sensillum at the tip of the antenna (figs $1 b, 5 b$ ).

4. Sensilla basiconica $\left(\mathrm{SB}_{4}\right)$ - these are sensilla basiconica that are smooth at the base and tapered at the tip. The rest of the surface is ribbed and porous. They are wider at the base and tapered along their length. These sensilla have been found in Ochterus marginatus on the $2^{\text {nd }}-4^{\text {th }}$ antennomere, where sensilla occur singularly or a few of them are spread on the surface. In Gelastocoris sp. on the $2^{\text {nd }}-4^{\text {th }}$ antennomere, sensilla occur singularly and in Gelastocoris flavus flavus they occur in groups or a few sensilla are arranged in line along the antennomere. These sensilla have also occurred singularly in Nerthra ranina on the $2^{\text {nd }}$ and $4^{\text {th }}$ antennomere. They are straight or bent towards the surface of the antenna (figs $1 b, 2 b$ ).

Sensilla coeloconica (SCo) - these are peg in pit sensilla, embedded in shallow open cavities of the cuticle. They are embedded in inflexible sockets. They are nonporous and occur among sensilla trichodea. These sensilla have been found in Ochterus on the $3^{\text {rd }}$ and $4^{\text {th }}$ antennomere, where sensilla occur singularly, in groups or in a line of a few sensilla, Gelastocoris flavus flavus where few sensilla have been observed on the $2^{\text {nd }}$ antennomere, Nerthra femoralis on the base and near the tip of the $4^{\text {th }}$ antennomere, where sensilla occur in groups or singularly and in Nerthra ranina where few sensilla have been found on the $4^{\text {th }}$ antennomere (figs 1c, f, 3a, c, 4e).

Sensilla plate-like $(\mathrm{SPl})$ - these are round sensilla, with uneven edges. They occur only on the distant half of the $4^{\text {th }}$ antennomere of Aphelocheirus and are more or less evenly distributed (fig. 5b).

Sensilla ampullacea (SA) - these are peg in pit sensilla with an external opening, which is cuticular and round, and in which no peg is visible because it is set internally at the bottom of a tube. Sensilla ampullacea rise from inflexible sockets. Single structures have been found in all of the studied species, in different locations throughout the antennae (figs $2 d, 5$ ). 
Sensilla placodea multilobated (SPM) these are round cavities with small oval protuberances, that do not extend beyond the cuticular surface. They have been observed in Nerthra species and Gelastocoris on the $3^{\text {rd }}$ and $4^{\text {th }}$ antennomere, distributed on the whole surface of the antennomere (figs 2c, $4 a, c)$.

\section{Discussion}

This paper summarizes our morphological studies of the external antennal sensilla in three families of Nepomorpha, performed with the use of a scanning electron microscope. This study is important for the continuation of other morphological studies on the nepomorphan taxa and suggests possible functions of sensilla based on their morphology and distribution on the antennae. Similar studies have already been done in two other families - Belostomatidae and Nepidae (Nowińska \& Brożek, 2019). More general research concerning the shapes of antennae and general occurrence of sensilla on the surface has been carried out by Popov (1971), Schuh \& Slater (1995) and Chen et al. (2005). During these studies, nine morphological types of sensilla have been observed and their probable functions have been indicated. Sets of sensilla were compared within the studied families, as well as with other nepomorphan families, semi-aquatic bugs (Gerromorpha) and other heteropteran species.

\section{Sensilla types}

The antennae of insects include many elementary sensilla, and they are treated as a complex multimodal insect organ (Chapman, 1998).

The morphological analysis of antennal sensory organs of the studied families (Ochteridae, Gelastocoridae and Aphelocheiridae) shows the presence of different sets of sensilla, forming three basal sensory systems: olfactory, tactile (mechanoreception) and thermo-hygroreceptive systems. The first system is composed by sensilla with wall pores (sensilla basiconica, plate-like sensilla and probably sensilla placodea multilobated). The second system - mechanoreception - includes different sensilla trichodea and chaetica as well as campaniformia and cone-shaped proprioceptive sensilla, all placed in flexible sockets and bearing characteristic nonporous surfaces. The hygro-thermoreceptive sensory system is represented by nonporous peg in pit sensilla (ampulacea) and sensilla coeloconica. All such sensilla are common in most insects (Chapman, 1998) as well as in nepomorphan nepid taxa (Nowińska \& Brożek, 2019) and in the currently studied families. However, their different polymorphic shapes constitute different subtypes, which may be assigned to different functions depending on their morphology and receptor's structures.

\section{Olfactory sensilla}

In Ochteridae (Ochterus marginatus) the olfactory system includes three subtypes of sensilla basiconica (SB2, $\mathrm{SB}_{3}$ and $\mathrm{SB}_{4}$ ) which are similar in both genera of Gelastocoridae (Gelastocorinae; Gelastocoris sp., G. flavus) and Nethra (Gelastocoridae: Nethrinae). All examined species of Gelastocoridae were found to share numerous sensilla placodea multilobated (SPM). A slight difference in the aforementioned taxa was observed in the olfactory system of Aphelocheiridae (Aphelocheirus aestivalis), in which only two types of sensilla basiconica ( $\mathrm{SB}_{2}$ and $\mathrm{SB}_{3}$ ) were observed, albeit in fewer numbers, as well as several plate-like sensillum (SP1). In the present study, all sensilla categorized as belonging to the olfactory system meet the standards regarding olfactory sensilla previously morphologically documented in other insects by many authors (Altner \& Prillinger, 1980; Chapman, 1998; Shields, 2010; Nowińska \& Brożek, 2017, 2019). 
At this stage of research, it is difficult to clearly indicate the extent of olfactory perception in these bugs, as they are mainly associated with the aquatic environment. The current data shows evident differences between relevant taxa, because sensilla $\mathrm{SB}_{3}$ or $\mathrm{SB}_{4}$ are present only in some of the studied species (table 1). SB3 is thin walled with many pores in contrast to the thick, grooved and porous sensilla $\mathrm{SB}_{4}$. Both types ( $\mathrm{SB}_{3}$ and $\left.\mathrm{SB}_{4}\right)$ of olfactory sensilla were recognized in many insect groups (Zacharuk, 1980; Brézot et al., 1997; Ahmad et al., 2016). It is significant that $\mathrm{SB}_{4}$ was recognized in taxa related to Ochteridae and Gelastocoridae. $\mathrm{SB}_{4}$ is only documented in one Nertha species. In turn, $\mathrm{SB}_{3}$ is pointed in Ochterus, Gelastocoris and Aphelocheirus, but probably absent in Nethra species. Such differences in sensilla sets may imply the specific reception of chemical compounds. Analyzing the distribution and number of olfactory sensilla on antennae in the particular taxa examined, several $\mathrm{SB}_{2}, \mathrm{SB}_{3}$ and $\mathrm{SB}_{4}$ were found on the penultimate and last antennomers (table 1) with the exception of Aphelocheirus, in which several SB2 occurred in groups on the penultimate and last antennomere, while $\mathrm{SB}_{3}$ was singularly located at the end of the last antennomere. In contrast, the presence of SB2 (thin walled multiporous) in all tested species can point to a monofunctional sensillum, probably responsible for the diagnosis of water chemistry.

Sensilla placodea multilobated (SPM) are found only in Gelastocoridae species and another type - plate like (SPl) - only in Aphchelocheiridae. The latter type is distributed on the last antennomere along its length and is believed to be a chemoreceptive sensillum. Moreover, this shape of sensillum has not been observed in Ochteridae. The expected characteristic pores are impossible to observe on the multilobated sensilla of gelastocorids and plate-like in aphelocheirid species, due to the pores' probable small size. However, this caveat does not exclude the sensilla's chemoreceptive function. These taxa, especially Aphelocheiridea, prefer stable water habitats (Andersen \& Weir, 2004). Particular features, such as the cuticle without pores in chemosensory sensilla, were found in other waterliving arthropods, thus reflecting a possible adaptation to the aquatic habitat (Gaino \& Rebora, 1999). Probably, these sensilla are highly specific for the mentioned taxa and responsible for specific behavior.

Structures similar to sensilla placodea multilobated have been discovered on heteropterans' bodies and described as sieve-pores (Cobben, 1978) or cuticular peg-plates (Andersen, 1982; Andersen \& Weir, 2004). However, the aforementioned authors did not identify any pores. Essentially, there is no clear information on whether these structures are glandular or sensorial. In the present study, the structures "sensilla placodea multilobated" are numerous and present on the antennae only in gelastocorid species. According to Slifer (1970), such grouped pegs in caves can be associated with an olfactory role, perceiving long distance stimuli. We observe significant discrepancies in chemical information detection sensilla, which are highly sensitive, due to aquatic insects's various adaptations to help in foraging, mating, reproduction, and assessment of predatory risk (Yee, 2014).

A fundamental prerequisite for nepomorphans and other aquatic insects is to be able to receive sensory cues in two very different biotopes during the immature and the adult stage, repectively. Olfactory systems consisting of different shaped sensilla basiconica (subtypes 2, 3) and coeloconica (subtypes 1, 2, 3) were also distinguished in other nepomorphan taxa (Nepidae and Belostomatidae) (Nowińska \& Brożek, 2019). However, the placoid-shaped olfactory sensilla did not occur. An important feature is the presence of a common type of olfactory sensillum basiconicum $\mathrm{SB}_{2}$ in all previously studied Nepoidea 
(Nowińska \& Brożek, 2019), as well as in all of the presently studied species. The occurrence of other different types of olfactory sensilla in Nepoidea is more characteristic for particular genera and species.

Generally, chemoreception in aquatic insects is the perception, via gustatory sensilla, of chemicals in an aqueous solution. If the insects are airborne, the chemicals are perceived by olfactory sensilla. Behavioral studies on the diving beetle Laccophilus maculosus showed that in the air, these beetles responded to about $10 \%$ of the concentration required to produce a similar response in water. A similar study pointed out that multiporous sensilla on the antennae of the diving beetle Graphoderus occidentalis are probably olfactory, but may also be sensitive to lower concentrations of chemicals in both air and water. It might indicate that the sensing of odors on both media is based on similar molecular and physiological processes (Jensen \& Zacharuk, 1992). It has also been reported that the great diving beetle Dytiscus marginalis (Linnaeus, 1758) has a very well developed chemoreceptive sensilla located on the antennae (odor) or maxillary and labial palpi (taste), which are critical for detecting potential food (Yee, 2014).

\section{Mechanoreceptive sensilla}

The study of insect's mechanoreceptive sensilla has a long history. The most obvious peripheral sense organs are the numerous cuticular hairs on the insects' bodies and appendages, called setae, which are a type of mechanoreceptive sensilla. McIver (1975) and others classified a variety of sensilla and inferred their functions from general observations on the insects' behaviours and on the structure and topography of the sensilla. In this way, it was determined that setiform/ hairform sensilla could monitor touch and indicate the flexion of joints; that campaniform sensilla could register bending of the cuticle, and that the curiously modified setiform sensilla of Nepa served as static organs under water (Chapman, 1998). The mechanoreception system of the antennae in the studied aquatic bug species is represented by trichoid sensilla of different shapes. Many trichoid sensilla are fine enough to detect air vibrations (Shields, 2010). Thus, these sensilla are numerous in terrestrial and semi-aquatic bugs (GonzagaSegura et al., 2013; Nowińska \& Brożek, 2018). Also, aquatic taxa can detect vibrations by using hair sensilla on the surface of water or while submerged. Hair sensilla (trichoid sensilla) are considered to be the structure from which all other types of sensilla are derived (McIver, 1970). They may appear as thick, hairlike or flattened structures (chaetica, clublike) or very fine hairs. Some of such hairs have peg-like or cone-like shapes. The present data shows mechanoreceptive sensilla in the three studied families as being composed of trichoid sensilla thin and smooth (ST1), slightly thick and ribbed (ST2) and thick and ribbed (chaetica, club-like) (SCh, SClL). All of these types of sensilla are numerous in representatives of Ochteridae and Gelastocoridae and less numerous in Aphelocheiridae and represent similar patterns of distribution. In Aphelocheirus, however, they were observed singularly and the types of mechanoreceptive sensilla were very limited on the antenommeres in comparison with the other nepomorphans (Nepidae and Belostomatidae), which also prefer the underwater life-style. Probably, the absence of long mechanoreceptive sensilla on the antennal surface in Aphelocheirus might be an adaptation to the type of environment. The antennae are situated on the head without any physical protection from environmental stressors, therefore not concealed in grooves beneath the eyes as observed in Gelastocoridae or Nepoidea (Popov, 1971; Nowińska \& Brożek, 2019). In Nepoidea, there is a great morphological diversity when it comes to mechanoreceptive sensilla, where Downloaded from Britl. come4/26/2023 09:29:35AM 
nine types were recognized, five of which were new for this group (Nowińska \& Brożek, 2019).

\section{Hygro-thermoreceptive sensilla}

Various kinds of sensilla are described and defined in the hygro-thermosensitive sensillar system (Altner \& Prillinger, 1980). Usually, sensilla hygro-thermosensitive appear as small aporous cuticular pegs (i.e., sensilla coeloconica) originating from the antennal surface or set in pits (sensilla ampulacea) (Tichy \& Kallina, 2013). Generally, water bugs fly from one body of water to another during mating season or to find new water habitats. They can also disperse in other ways (Wróblewski, 1980). Temperature and humidity are major determinants of distribution patterns for species. In Gelastocoridae, some species are not able to fly (due to fused hemielytra) and in others flight has not been observed, but nonetheless these species are frequently found away from water. It seems like this kind of hygro-thermosensitive sensilla is essential for finding other water reservoirs (Chen et al., 2005). This might explain the presence of several sensilla ampullacea and sensilla coeloconica in the studied species. In Aphelocheirus, which happens to be the only species living submerged, numerous sensilla ampullacea occur. These have been found along with sensilla $\mathrm{SPl}$, on the last antennomere. However, several sensilla coeloconica (SCo) have also been found in species of Gelastocoridae and Ochteridae, localized mainly on the $3^{\text {rd }}$ and $4^{\text {th }}$ antennomeres. Moreover, sensilla ampullacea were in different locations throughout the antennae in these taxa. In Nepoidea, sensilla coeloconica (three subtypes) with the same structure also occurred (Nowińska \& Brożek, 2019). Therefore, we cannot exclude the potential hygro-thermoreceptive function of sensilla ampulacea and coeloconica. Moreover, these sensilla, especially sensilla coleoconica, are aporous sensilla with inflexible sockets and few in number. According to Altner (1983), such morphological characters of the sensilla represent one fundamental sensillum type and their structural features can be regarded as adaptations to hygro- and thermoreception. The bimodal hygro-thermoreceptive sensilla exhibited the strongest responses to changes in humidity as well as temperature changes, because the moist cells' and the dry cells' discharge rates increase with high temperatures. This phenomenon was observed i.e., in Periplaneta americana (Tichy \& Kallina, 2013).

\section{Comparison to the other heteropteran groups}

It is significant that within Nepomorpha there are two types of antennae. In Ochteridae and Aphelocheiridae the antennae are long and extend over the head, making them very similar to the long and thin antennae in Gerromorpha and other heteropterans (Andersen, 1982; Shuch \& Slather, 1995), while in Nepoidea, the antennae are short and concealed beneath the head, as in Gelastocoridae (La Rivers, 1953; Menke, 1979; Zettel \& Lane, 2010). Nonetheless, both types of antennae involve complex sensilla of different modalities and appearance, despite a common underlying architecture.

Generally, a sensillar system is conserved throughout the different insect orders, making it improbable that these different types of sensilla have evolved independently several times (Steinbrecht, 1997). That is probably why a similar set of functional sensilla is observed in terrestrial and aquatic heteropteran insects.

However, the adaptive value of conserving both types of olfactory sensilla ('single-walled wall-pore', 'double-walled wall-pore') throughout almost all insect taxa to date requires further verification (Steinbrecht, 1997). The sensory peg of the double-walled sensilla is smooth at the base and has a grooved cuticular 
surface distally, with pores organized in spoke channels between each ridge, in contrast to the single-walled sensilla with a porous thin cuticular wall. Also, sensilla basiconica distinguished in the presently studied water taxa, belong to both 'single-walled wall pore' ( $\mathrm{SB}_{2}$, $\left.\mathrm{SB}_{3}\right)$ and 'double-walled wall pore' classes $(\mathrm{SB} 4)$. Olfactory sensilla basiconica $\left(\mathrm{SB}_{2}\right)$ are present in all studied taxa and the remaining sensillar types ( $\left.\mathrm{SB}_{3}, \mathrm{SB}_{4}\right)$ have different configurations according to subfamilies/species. In the studied taxa, sensilla ampulacea (SA), campaniformia (SCa) and trichoidea (ST2) belong to a standard set of sensilla, just like SB2. Probably, these sensilla (SB2, ST2, SA, SCa) originated from the protoheteropteran line and retain plesiomorphic sensillar features. Hence, we observe some common features of Ocheroidea and Aphelocheiridae with Nepoidea. Among the other types of sensilla, significant changes in their shape, size and distribution were demonstrated in the studied taxa. Sensilla placodea (usually olfactory) are not common in nepomorphan taxa (except Aphelocheiridae), as sensilla placodea multilobated are characteristic of one family (Gelastocoridae). In Nepoidea, however, sensilla coeloconica (subtypes 1, 2, 3) were recognized as multiporous chemoreceptive sensilla (Nowińska \& Brożek, 2019), whereas in the presented taxa, sensilla coeloconica are recognized as hygro-thermoreceptive sensilla. Other heteropteran taxa/species display a presence of multiporous sensilla basiconica or trichodea ('single-walled wall-pore', 'doublewalled wall-pore') on the antennae, while sensilla placodea are rarely present. However, often their shape, size and number are slightly varied, like in reduviids (Catalá, 1997; Gracco \& Catalá, 2000; Guerenstein \& Guerin, 2001; Carbajal de la Fuente \& Catalá, 2002; Slu, 1980), miriids (Chinta et al., 1997), Alydidae (Rani \& Madhavendra, 2005; Ventura \& Panizzi, 2005), lygaeids (Rani \& Madhavendra, 2005), pentatomids (Rani \& Madhavendra, 1995; Brézot et al., 1997; Sinitsina \& Chaika, 1998; Ahmad et al., 2016), coreids (Akent'eva, 2008) and in Gerromorpha (Nowińska \& Brożek, 2017). The thermo-hygroreceptive sensilla found in the studied families (ampulacea or aporous sensilla coeloconica) are mostly the same types and functions, although their size and how they are embedded is different. Aporous sensilla coeloconica on the flagellum can also be regarded as playing a thermo-hygroreceptive role, in other insects/heteropteran species: Nezara viridula (Pentatomidae), Odontopus nigricornis (Pyrrhocoridae), Cyclopelta siccifolia (Dinidoridae),Chrysocoris purpureus (Scutelleridae), Piezodorus guildinii (Pentatomidae), Leptoglossus zonatus (Coreidae) as well as in some gerromorphan species (Usha Rani \& Madhavendra, 1995, 2005; Brézot et al., 1997; Chapman, 1998; Silvaet al., 2010 Ruchty, 2009; Gonzaga-Segura et al., 2013 Nowińska \& Brożek, 2017; Schneider, 2018). For terrestrial heteropteran insects, another common type of mechanoreceptive sensilla is sensilla trichodea, but usually in different lengths and even distributions on all antennomeres, similar to mechanoreceptive sensilla basiconica. Sensilla chaetica are less numerous than sensilla trichodea and are sparsely distributed or only occur as single structures in different terrestrial heteropteran taxa. Sensilla campaniformia show a uniform structure in all mentioned taxa (Chinta et al., 1997; Slu, 1980; Akent'eva, 2008; Ahmad et al., 2016; Nowińska \& Brożek, 2017).

Ochteridae is more connected with terrestrial environments (Andersen \& Weir, 2004), therefore similarities with the antennal sensilla of terrestrial Heteroptera could have been expected, which is different from what is observed in Gelastocoridae and Aphelocheiridae. Present studies have shown that the main sets of antennal sensilla in these three families (table 1, fig. 6) are generally similar to those in Nepoidea - insects submerged in water. Multiple types of mechanoreceptive 
and chemoreceptive sensilla were documented in all of them. Sensillum club-like, which was new for Nepoidea, was also observed during the presented studies and sensilla ampullacea works as the main thermohygroreceptive sensillum for all the families in Nepoidea as well as within the presently studied species.

The main difference between nepoid groups (six types of mechanoreceptive sensilla in Belostomatidae and seven types in Nepidae) (Nowińska \& Brożek, 2019) and the families mentioned above, is the fewer amount of mechnoreceptive sensilla types (three: trichodea, chaetica and campaniformia). These differences in structure/types of sensilla in particular taxa show how sensory systems have adapted to new lifestyles, and future studies on other nepomorphan families may show further new features.

\section{Short phylogenetic remarks for studied groups}

In the present study, the antennal sensilla (ST1, ST2, SCh, SB1 SB2, SCa, SCo) are presumably plesiomorphic, due to having the same shapes and similar distributions of the sensilla as reported in Nepoidea (Nowińska \& Brożek, 2019) - the superfamily considered to be the primary taxon of Nepomorpha (Popov 1971, Hebsgaard et al., 2004, Brożek, 2014).

On the other hand, sensilla placodea multilobated (SPM) have been reported only in the species of Gelastocorinae and Nerthrinae and probably represent an evolutionary novelty for them, therefore being synapomorphic.

Sensillum basiconicum (SB4) has been observed only in ochterid and gelastocorid species and is a synapomorphic feature of Gelastocoridae and Ochteridae, and therefore, a confirmation of their close relationship. There is more evidence to suggest a close relationship between Gelastocoridae and Ochteridae, which together compose Ochteroidea (Hebsgaard, et al., 2004). The presence of sensilla plate-like (SPl) only in Aphelocheiridae, on the other hand, indicates an autapomorphy.

Currently and according to expectations, we have not found any signs indicating a relationship between Ochteroidea and Aphelocheiridae, because the taxon is quite distant from the family. Future study of antennal sensilla in naucoroid species may be of importance when it comes to phylogenetic considerations.

\section{Conclusions}

The studied families show variations in their adaptation to aquatic habitats, as well as in antennae's shapes. The basal set of sensilla (ST2, $\mathrm{SCa}, \mathrm{SB} 2, \mathrm{SA}$ ) is similar in all of them and is not different from the sensilla present in Nepoidea (ST2, SCa, SB2, SA). They share the same type of sensillum (SClL) which is new to Nepomorpha, and all of the studied families, as well as Nepoidea, use mainly sensilla ampullacea for thermo-hygroreception. On the other hand, the shapes of antennae and sets of sensilla in the studied families of Nepomorpha are different compared to semi-aquatic bugs (Gerromorpha). There are more sensilla subtypes in Gerromorpha (18) and their antennae are very long and thin, while the antennae of the studied species bear fewer types of sensilla, are much shorter and, in some species (Gelastocoridae), concealed beneath the eyes. The antennae of Aphelocheiridae bear sparsely distributed sensilla, which are mostly sensilla basiconica. It is possible that the number of sensilla has been reduced because of their preference for running water habitats. The antennae of Ochteridae and Gelastocoride are mostly covered by sensilla trichodea, with lone sensilla basiconica and coeloconica sparsely distributed on the surface. There were two types of thermo-hygroreceptive sensilla present in the families - sensillum ampullaceum and sensillum coeloconicum. New 
types of sensilla, characteristic of the antennae of Aphelocheiridae (SPl) and Ochteroidea (SPM), have also been found. This supports our hypothesis that the antennal sensilla of the studied families reflect their different adaptations for use in aquatic habitats, while maintaining a common set of sensilla similar to other nepomorphan insects. The study also confirms the systematic position of Ochteridae as closely related to Gelastocoridae. Antennal sensilla of Naucoroidea will be studied in the future. Therefore, we expect to compare present results of Aphelocheiridae with other species of Naucoroidea and apply a cladistic method for a more thorough assessment of their phylogenetic significance.

\section{Acknowledgements}

The authors would like to thank $\mathrm{H}$. Zettel from the Natural History Museum in Vienna, Yu. A. Popov from the Zoological Museum of the State Moscow University and P. Kobor from the Hungarian National History Museum for the access to their respective nepomorphan collections, Ping-ping Chen for donating additional species of Nerthra and Gelastocoris, and J. Karcz from the University of Silesia in Poland for help in SEM documentation in the Laboratory of Scanning Microscopy. We also thank Dan Polhemus and an anonymous reviewer for their useful comments that helped improving the paper.

\section{References}

Ahmad, A., Parveena, Sh., Brożek, J. \& Dey, D. (2016) Antennal sensilla of phytophagous and predatory pentatomids (Hemiptera: Pentatomidae): a comparative study of four genera. Zool. Anz., 261, 48-55.

Akent'eva, N.A. (2008) The formation of the antenna sensory apparatus in some bug (Heteroptera) species in the course of their postembryonic development. Entomol. Rev., 88, 381-390.

Altner, H. \& Prillinger, L. (1980) Ultrastructure of invertebrate chemo- thermo- and hygroreceptors and its functional significance. Int. Rev. Cytol., 67, 69-139.

Altner, H., Schaller-Selzer, L., Stetter, H. \& Wohlrab, I. (1983) Poreless sensilla with inflexible sockets. Cell Tissue Res., 234, 279-307.

Andersen, N.M. (1982) The Semiaquatic Bugs (Hemiptera, Gerromorpha) Phylogeny, Adaptations, Biogeography and Classification. Scandinavian Science Press Ltd, Klampenborg.

Andersen, N.M. \& Weir, T.A. (2004) Australian Water Bugs. Their biology and identification (Hemiptera-Heteroptera, Gerromorpha \& Nepomorpha). Entomonograph, 14, 1-344.

Brézot,P.,Tauban,D.\&Renou,M.(1997)Senseorgans on the antennal flagellum of the green stink bug, Nezara viridula (L.) (Heteroptera: Pentatomidae): sensillum types and numerical growth during thepost-embryonic development.Int.J.Insect Morphol.Embryol., 25,427-441.

Brönmark, C. \& Hansson, L.A. (2000) Chemical communication in aquatic systems: an introduction. Oikos, 88, 103-109.

Brożek, J. (2013) Comparative analysis and systematic mapping of the labial sensilla in the Nepomorpha (Heteroptera: Insecta). Sci. World J., 2013, 1-44.

Brożek, J. (2014) Phylogenetic signals from nepomorpha (Insecta: Hemiptera:Heteroptera) mouthparts: stylets bundle, sense organs, and labial segments. Sci, World J, 2014, 1-30.

Carbajal de la Fuente, A.L. \& Catalá, S.S. (2002) Relationship between antennal sensilla pattern habitat in six species of Triatominae. Mem. Inst. Oswaldo Cruz, 97, 1121-1125.

Catalá, S.S. (1997) Antennal sensilla of Triatominae (Hemiptera, Reduviidae): a comparative study of five genera. Int. J. Insect. Morphol. Embryol., $26,67-73$.

Chaika, S.Y. \& Sinitsina, E.E. (1999) Sensory organs of the labium and antennae in water bugs (Heteroptera). Entomol. Obozr., 78, 40-59. Downloaded from Brill.com@4/26/2023 09:29:35AM 
Chapman, R.F. (1998) Mechanoreception. Chemoreception. In: R.F. Chapman (Ed) The Insects, Structure and Function, pp. 610-652. Cambridge University Press, Cambridge.

Chen, P.-P., Nieser, N. \& Zettel, H. (2005) The Aquatic and Semi-Aquatic Bugs (Heteroptera: Nepomorpha \& Gerromorpha) of Malesia. Fauna Malesiana Handbook 5. Brill, Leiden, Boston.

China, W.E. (1955) The evolution of the water bugs. Symposium on organic evolution. Bull. Nat. Inst. Sci., India, 7, 91-103.

Chinta, S., Dickens, J.C. \& Baker, G.T. (1997) Morphology and distribution of antennal sensilla of the tarnished plant bug, Lygus lineolaris (Palisot de Beauvois) (Hemiptera: Miridae). In.t J. Insect Morph. Embryol., 26, 21-26.

Cobben, R.H. (1978) Evolutionary Trends in Heteroptera-Part 2: Mouthpart-Structures and Feeding Strategies. Mededelingen Landbouwhogeschool, Wageningen.

Crespo, J.G. (2011). A review of chemosensation and related behavior in aquatic insects. J. Insect Sci., 11, 62 .

Gaino, E. \& Rebora, M. (1999) Larval antennal sensilla in water-living insects. Microsc. Res. Tech., $47,440-457$.

Gonzaga-Segura,J., Valdéz-Carrasco, J. \& CastrejónGómez, V.R. (2013) Sense organs on the antennal flagellum of Leptoglossus zonatus (Heteroptera: Coreidae). Ann. Entomol. Soc. Am., 106, 510-517.

Gracco M. \& Catalá S. (2000) Inter-specific developmental differences on the array of antennal chemoreceptors in four species of triatominae (Hemiptera, Reduviidae). Mem Inst Oswaldo Cruz, 95, 67-73.

Grimaldi, D. \& Engel, M.S. (2005) Evolution of the Insects. Cambridge University Press, New York.

Guerenstein, P.G. \& Guerin, P.M. (2001) Olfactory and behavioural responses of the blood-sucking bug Triatoma infestans to odours of vertebrate hosts. J. Exp. Biol,. 204, 585-597.

Hallberg, E. \& Hansson, B.S. (1999) Arthropod sensilla: morphology and phylogenetic consideration. Microsc. Res. Tech., 47, 428-439.
Hebsgaard, M.B., Andersen, N.M. \& Damgaard, J. (2004) Phylogeny of the true water bugs (Nepomorpha: Hemiptera-Heteroptera) based on $16 \mathrm{~S}$ and $28 \mathrm{~S}$ rDNA and morphology. Syst. Entomo.l, 29, 488-508.

Jensen, J.C. \& Zacharuk, R.Y. (1992) The fine structure of the multiporous sensilla on the antenna of the diving beetle Graphoderus occidentalis Horn (Coleoptera: Dytiscidae). Can. J. Zool., 70, 825-832.

Kment, P. \& Jindra, Z. (2008) Review of the family Gelasotocoridae (Heteroptera: Nepomorpha) of South-Eastern Asia. In: S. Grozneva \& N. Simov (Eds) Advances in Heteroptera Research. Pensoft Publishers, Sofia, Bulgaria, 189-213.

La Rivers, I. (1953) New Gelastocorid and naucorid records and miscellaneous notes, with a description of a new species, Ambrysus amargosus (Hemiptera: Naucoridae). Wasmann J. Biol., 11, 83-96.

McIver, S.B. (1975) Structure of cuticle mechanoreceptors of arthropods. Annu. Rev. Entomol, 20, 381-397.

Menke, A.S. (1979) The semiaquatic and aquatic Hemiptera of California (Heteroptera: Hemiptera). Bull. Calif. Insect. Surv., 21, 70-86.

Nieser, N. (2002) Guide to aquatic Heteroptera of Singapore and Peninsular Malaysia. IV. Corixoidea. Raffles Bull. Zool, 50, 263-274.

Nowińska, A. \& Brożek, J. (2017) Morphological study of the antennal sensilla in Gerromorpha (Insecta: Hemiptera: Heteroptera). Zoomorphology, 136, 327-347.

Nowińska, A. \& Brożek, J. (2019) Antennal sensory structures in water bugs of Nepoidea (Insecta: Hemiptera: Nepomorpha), their morphology and function. Zoomorphology, 138, 307-319.

Papáček, M. (2001) Small aquatic and ripicolous bugs (Heteroptera:Nepomorpha) as predators and prey: the question of economic importance. Eur. J. Entomol., 98, 1-12.

Polhemus, J.T., Jansson, A. \& Kanyukova, E. (1995) Infraorder Nepomorpha - water bugs. In: B. Aukema \& C. Rieger (Eds) Catalogue of the Heteroptera of the Palaearctic Region. Volume 1. Downloaded from Brill.com๑4/26/2023 09:29:35AM 
Enicocephalomorpha, Dipsocoromorpha, Nepomorpha, Gerromorpha \& Leptopodomorpha. Ponsen \& Looijen, Wageningen, $13-75$.

Polhemus, D.A. \& Polhemus, J.T. (1988) The Aphelocheirinae of Tropical Asia (Heteroptera: Naucoridae). Raffles Bull. Zool., 36, 167-300.

Popov, Y.A. (1971) Historical Development of the Hemipterous Infraorder Nepomorpha. Trudy Paleontological Institute Academy of Science, Nauk, USSR.

Rani, P.U. \& Madhavendra, S.S. (1995) Morphology and distribution of antennal sense organs and diversity of mouthpart structures in Odontopus nigricornis (Stall) and Nezara viridula L. (Hemiptera). Int. J. Insect. Morphol. Embryol., 24, 119-132.

Rani, P.U. \& Madhavendra, S.S. (2005) External morphology of antennal and rostral sensillae in four hemipteran insects and their possible role in host plant selection. Int.J. Trop. Insect Sci., 25, 198-207.

Ruchty, M., Romani, R., Kuebler ,L.S., Ruschioni, S., Roces, F., Isidoro, N. \& Kleineidam, C.J. (2009) The thermo-sensitive sensilla coeloconica of leaf-cutting ants (Atta vollenweideri). Arthropod. Struct. Dev., 38, 195-205.

Schuh, R.T. \& Slater, J.A. (1995) True Bugs of the World (Hemiptera: Heteroptera). Classification and Natural History. Cornell University Press, New York.

Shields, V.D.C. (2010) High resolution ultrastructural investigation of insect sensory organs using field emission scanning electron microscopy. In: V.A. Mendez \& J. Diaz (Eds) Microscopy: Science, Technology, Applications and Education. Formatex, Badajoz, 321-328.

Schneider, E.S., Kleineidam, C.J., Leitinger, G. \& Römer, H. (2018) Ultrastructure and electrophysiology of thermosensitive sensilla coeloconica in a tropical katydid of the genus Mecopoda (Orthoptera, Tettigoniidae). Arthropod. Struct. Dev., 47, 482-497.

Sinitsina, E.E. \& Chaika, S.Y. (1998) The Antenna sensory apparatus of terrestrial bugs (Heteroptera). Zool. Zh., 77, 1273-1284.
Slifer, E.H. (1970) The structure of arthropod chemoreceptors. Annu. Rev. Entomol., 15, 121-141.

Slu, C. (1980) Ultrastructure of the antennal sensillae of the bug, Rhodnius prolixus (Hemiptera, Reduviidae). Parazitologiia, 14, 92-486.

Tichy, H. \& Kallina, W. (2013) The evaporative function of cockroach Hygroreceptors. PloS One, 8, 1-19.

Todd, E.L. (1955) A taxonomic revision of the family Gelastocoridae. Kans. Univ. Sci. Bull., 37, 277-475.

Ventura, M.U. \& Panizzi, A.R. (2005) Morphology of olfactory sensilla and its role in host plant recognition by Neomegalotomus parvus (Westwood) (Heteroptera: Alydidae). Braz, Arch, Biol, Technol, 48, 589-597.

Wróblewski, A. (1980) Pluskwiaki (Heteroptera). Fauna słodkowodna Polski, PWN, Warszawa -Poznań.

Wisenden, B.D. (2000) Olfactory assessment of predation risk in the aquatic environment. Philos. Trans. R. Soc. Lond., B, Biol. Sci., 355 (1401), 1205-1208.

Ye, Z., Damgaard, J., Yang, H., Hebsgaard, M.B., Weir, T. \& Bu, W. (2020) Phylogeny and diversification of the true water bugs (Insecta: Hemiptera: Heteroptera: Nepomorpha). Cladistics, 36 (1), 72-87.

Yee, D.A. (2014). An Introduction to the Dytiscidae: Their Diversity, Historical Importance, Cultural Significance, and Other Musings. Ecology, Systematics, and the Natural History of Predaceous Diving Beetles (Coleoptera: Dytiscidae). Springer, Dordrecht, Berlin.

Zacharuk, R.Y. (1980) Ultrastructure and function of insect chemosensilla. Annu. Rev. Entomol,. 25, 27-47.

Zettel, H. \& Lane, D.J.W. (2010) A new species of Ochterus Latreille (Heteroptera: Ochteridae) from Brunei. Z. Arb. Gem. Öst. Ent., 62, 97-101.

RECEIVED: 21 JANUARY 2020 | REVISED AND

ACCEPTED: 17 APRIL 2020

EDITOR: H. DE. JONG 